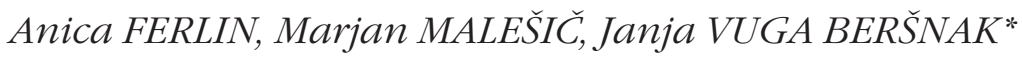

\title{
PREPAREDNESS VS. IMPROVISATION: A RESPONSE TO THE COVID-19 CRISIS IN SLOVENIA
}

\begin{abstract}
Crisis response planning can never fully prevent a certain amount of improvisation given that, in some cases, it is necessary, if not even desirable. This article analyses the research question on the relationship between crisis planning and improvisation in theory and with respect to the Covid-19 epidemic in Slovenia. Despite existing systemic recommendations, normative and to some extent operational crisis preparedness, our analysis of the country's response reveals improvisation in several key elements: planning, decision-making, coordination and crisis communication. The quite considerable improvisation seen with the epidemic is the outcome of its unexpected dimensions, the absence of a comprehensive crisis management plan, and individual actors' insufficient crisis management competences. It has been reflected in the establishing of specialised ad hoc structures, overnight decisions and their sudden reversals, and often in inconsistent and inappropriate communication with the public.
\end{abstract}

Keywords: preparedness, improvisation, planning, decision-making, coordination, crisis communication, Covid-19 epidemic

\section{Introduction}

Contemporary crises are usually intense and complex, dictating the need for an integrated crisis management approach. The Covid-19 pandemic is one of the most complex crises the world has ever faced. It has put in jeopardy fundamental social values, norms and structures, requires prompt decision-making, brings uncertainty and stress to the affected populations, and it came as a big surprise to ordinary people and decision-makers. During the Covid-19 pandemic, countries along with their crisis management systems and decision-makers have needed to deal with the 'unknown' due to

* Anica Ferlin, PhD Student, Faculty of Social Sciences, University of Ljubljana, Slovenia; Marjan Malešič, PhD, Professor, Faculty of Social Sciences, University of Ljubljana, Slovenia; Janja Vuga Beršnak, PhD, Associate Professor, Faculty of Social Sciences, University of Ljubljana, Slovenia. DOI: $10.51936 /$ tip.58.specialissue.632-651 
insufficient reliable information with scientific backing. Time has been one of the most critical elements, forcing prompt decisions and actions in an attempt to control the situation as much as possible. As part of this, governments in various countries, including Slovenia, have relied on both planned and improvised measures.

Improvisation in response to crises has in recent years attracted the attention of researchers (e.g. Webb and Chevreau, 2006; Wachtendorf and Kendra, 2005 and 2006; Tierney, 2012; Mendonca et al., 2014; Kendra and Wachtendorf, 2006 and 2016; Deterala and Villar, 2019). The purpose of this article is to add to this body of expertise by exploring the relationship between envisaged legal solutions and actual actions in response to the Covid-19 crisis in Slovenia during 2020. The authors consider four intertwined crisis management activities performed by the authorities: planning, decision-making, coordination and crisis communication. The article refers to the period of the first wave of the epidemic in spring and the initial part of the second wave of the epidemic from October to the end of December 2020. The research question is: To what extent were the actions of the crisis management authorities planned and prepared for, and to what extent were those actions a matter of improvisation? The article focuses on the political level of crisis management and the performance of actors on the national level, rather than the local one. To answer the research question, the authors first analyse recent literature on the planning (preparedness)-improvisation relationship, and describe it. This is followed by content analysis of official Republic of Slovenia documents in the field of crisis management so as to reveal key planned structural and functional solutions. The authorities' actual response to the crisis as documented in official statements and released by various traditional and social media is then analysed. Concluding remarks are based upon a comparison of the planned and improvised actions of Slovenian authorities taken in response to the Covid19 crisis.

\section{Preparedness (planning) and improvisation}

Planning is hugely important to ensure an adequate response to a crisis. According to Alexander (2020), emergency planning should be holistic and responsive. A plan should be constantly refined, updated, and known by those who may be expected to use it. A plan should also be logical, systematic, include previous knowledge and experiences, and enable the efficient use of resources. Wachtendorf and Kendra (2005) believe the plan should summarise the institutional knowledge, namely that which exceeds the knowledge and experience held by individuals involved in previous crises. Through the planning process, the organisation envisages possible 
scenarios of a crisis and its development; it also stimulates the development of (in)formal networks and enables coordination among organisations. Prezelj (2007: 14-15) warns that poor and improper crisis management planning can affect the scope, intensity and duration of a crisis. Plans must be comprehensive, with a clear division of responsibilities and take place on all levels involved in the crisis response. Vuga and Ferlin (2018: 55) state that crisis management plans should chiefly include an up-to-date threat assessment, and a description of the activities, roles and responsibilities of all crisis-management bodies, state and other services based on their function within the crisis management process. The plan should include a detailed response to the crisis and identify the necessary response measures, capabilities and resources and expected measures to limit the impacts of the crisis.

Improvisation, in contrast, is a way of processing knowledge and experience to timely perform a new action due to unclear and dynamic circumstances not (fully) envisaged by a plan. Crises affect society, but do not destroy it. The disorganisation seen after a crisis is in essence the community's adaptation to the changing environment and new circumstances (cf. Wachtendorf and Kendra, 2005).

When the normative framework does not provide sufficient guidance for joint action, the actors involved should improvise in order to deal with the crisis. Nevertheless, the newly created solutions are generally closely connected to the solutions envisaged in the pre-crisis period. The structures formed in advance, planned actions, jurisdictions, and resources establish a basis for crisis-related decision-making. Planning ensures a certain level of stability in terms of organisational structures, roles, tasks and responsibilities, resources, and the physical environment; this also holds in situations that require the taking of unplanned actions. Concurrently, the need for improvisation is due to the inability of plans to properly take account of one or more specific requirements. It is neither practical nor feasible to envisage every possible scenario in a crisis' course. Crisis response without improvisation loses the adaptability and efficiency that may be required by changing circumstances. Even a modest level of preparedness enhances the possibility to improvise. Hence, preparedness (planning) and improvisation are closely connected phenomena (Wachtendorf and Kendra, 2005).

The ratio between planned activities and improvised ones varies. According to Mendonca et al. (2014), emergency response actions range from conventional to improvised. Crisis response teams' enactment of improvisation takes place "in terms of a spectrum of deviance that ranges from slight deviation to total overhaul" (Deterala and Villar, 2019: 5). Alternatively, "improvisations may range from simple substitution of planned-for /.../ to more profound changes" (Mendonca et al., 2014: 2). 
While organisations create a certain system for use during crises, its disturbed functioning negatively affects the performance of activities and tasks, destabilises organisational structures, and destroys or limits the use of resources (Wachtendorf and Kendra, 2005). In response to fluid circumstances, the organisation or a group of organisations observe the changing environment, decide whether the system's original elements are still necessary and appropriate and improvise to do what is necessary to adequately respond to the crisis.

Pina e Cunha et al. (2019) suggest that organisations that wish to continue functioning in the case of extreme dynamic complexity apply imagination, ingenuity, and new modes of functioning. In such a dynamic and complex situation, when the context is ever-changing, traditional methods are not necessarily that useful; still, continuous functioning remains important. Improvisation is a response to an unexpected or unplanned event, and a crucial element of an organisation's functioning in changing circumstances. Frykmer et al. (2018) emphasise that improvisation is in essence a tool for functioning in uncertain circumstances in which a preconceived plan is either unuseful or has limited use.

On the contrary, some authors (e.g. Kreps, 1991, Drabek, 2001 and Alexander, 2020) implicitly suggest that improvisation is something negative that organisations should avoid. We believe that if improvisation is not enforced by the crisis but is an outcome of organisations being ill-prepared, their individualistic uncoordinated actions, ignoring of the normative framework, and negligence of planned structures and solutions, then (and only then) can improvisation be regarded as a negative phenomenon.

\section{Crisis management structure: prepared official documents and improvised actions}

Although initially considered a health crisis, the Covid-19 epidemic in Slovenia quickly reached the dimensions of a complex crisis pursuant to the Government of the Republic of Slovenia Act (Official Gazette of the Republic of Slovenia, Nos 24/05 - 55/17, Article 20). According to the Act, a complex crisis poses a serious threat to fundamental social values and exceeds the response capabilities of individual ministries, government services and subsystems of the national security systems. Another feature of a complex crisis is the relatively short response time, meaning all stakeholders must be prepared, trained and aware of their role and responsibilities. This should be guaranteed by a fully functioning crisis management structure or system. Based on attempts lasting over a decade to systemically regulate crisis management together with the conclusions of a government strategic project (see Final Report P7, 2016; Vuga and Ferlin, 2018), crisis management was 
normatively implemented in the Government of the Republic of Slovenia Act (Official Gazette of the Republic of Slovenia, Nos 24/05 - 55/17) and inserted into a key strategic national security document, the Resolution on the National Security Strategy of the Republic of Slovenia (Official Gazette of the Republic of Slovenia, No. 59/19).

The political-level response to a complex crisis should be conducted by a 'crisis management structure' composed of several bodies with different roles and responsibilities. Under The Government of the Republic of Slovenia Act, the government remains the decision-maker in a crisis, with the National Security Council acting as its body for consultation. The National Security Council Secretariat may coordinate the response during a complex crisis and prepare response proposals. Information and communication support for the government and other bodies is provided by the National Crisis Management Centre, whereas its Interdepartmental Analytical Group provides analytical and professional support, and the Government Communication Office ensures crisis communication coordination. The crisis management structure also includes the National Security Council Secretariat Operational Group whose members are redeployed to the Interdepartmental Analytical Group during a crisis but play a significant role in threat assessment, crisis planning, crisis exercises etc. in the pre-crisis period (Official Gazette of the Republic of Slovenia, Nos 24/05 - 55/17; Final Report P7, 2016: 27-33).

The specific tasks, roles and responsibilities of bodies in the crisis management structure are further elaborated in the Decree on crisis management and governance and on the National Crisis Management Centre (Official Gazette of the Republic of Slovenia, No. 28/18) and the Decree on National Security Council (Official Gazette of the Republic of Slovenia, No. 26/20). The former stipulates that in the event of a complex crisis the government should make a decision to take over and lead the response. After such a decision, which should be made on the proposal of the responsible stakeholder (either a ministry or a subsystem of the national security system), all of the mentioned bodies are activated and provide the functions needed to ensure an effective crisis response: monitoring, analysing and anticipating, consulting, decision-making, coordination, communication and support functions (e.g. information and communication support, psychosocial assistance etc.). The Decree on crisis management and governance and on the National Crisis Management Centre also outlines monitoring and reporting, crisis planning and exercises, crisis communication and post-crisis analysis while the composition and operation of the National Security Council and its Secretariat are further defined in the Decree on the National Security Council (Official Gazette of the Republic of Slovenia, No. 28/18, Official Gazette of the Republic of Slovenia, No. 26/20). 
When the Covid-19 crisis hit Slovenia, an epidemic was declared on 12 March 2020 under Article 7 of the Infectious Diseases Act (Official Gazette of the Republic of Slovenia, Nos 33/06 - 175/20) dating back to 2006 ${ }^{1}$. This Act regulates the declaration of an epidemic, different types of infectious diseases and special measures to prevent and control their spread, monitoring, supervision, the role of the Police, vaccination, and liability under this act. While the Act does not classify an epidemic as a potential complex crisis, the case of the flu epidemic was recognised as such just days before the first Covid-19 case in Slovenia. Although an epidemic of a different type but with the same proportions had been listed as a complex crisis, the very new government, sworn in on 13 March 2020, instead of resorting to the existing solutions and activating the crisis management bodies, established a new improvised structure - the Crisis Staff - led by the prime minister (GOV. SI, 14 March 2020). The government ignored the crisis management bodies when amending the Infectious Diseases Act as a key foundation of most of the measures taken and also simultaneously amended the Decree on the National Security Council and abolished the National Security Council Secretariat Operational Group. This led to inconsistency between the amended Decree with the Resolution on the National Security Strategy of the Republic of Slovenia and the Government of the Republic of Slovenia Act.

\section{Empirical results concerning improvisation during the Covid-19 epidemic in Slovenia}

\section{Crisis management planning}

Based on the Decree on crisis management and governance and on the National Crisis Management Centre, crisis management plans for all possible complex crises should be drawn up by ministries and responsible bodies, preparation activities should be coordinated by the National Security Council Secretariat Operational Group, while plans should be confirmed by the government. The deadlines set out in the Decree meant that the ministries and other responsible bodies had to prepare a list of potential crises by the end of October 2018, which was then to be confirmed by the government and, by the end of 2019, followed by crisis management plans for the complex crises so identified (Official Gazette of the Republic of Slovenia, No. 28/18).

However, the expected crisis management planning activities were not completed within the estimated and legally binding timeframe. The previous government had merely confirmed the list of potential complex crises,

\footnotetext{
1 Amended during the first and second lockdowns in April and October 2020, respectively.
} 
including an epidemic, only days before it was replaced. This delay meant Slovenia was missing a comprehensive crisis management plan covering the political and operational response to a complex health crisis when the Covid-19 epidemic was already on its doorstep. Hence, Slovenia missed the opportunity to learn from the flaws identified during the migration crisis and improve its preparedness for the crises to come (Sotlar, Grizold and Vuga Beršnak, 2020).

Notwithstanding the absence of a crisis management plan for an epidemic on the national level, there has long been the National Protection and Rescue Plan in the event of a communicable disease epidemic or pandemic in humans ('the National Protection and Rescue Plan'). The National Protection and Rescue Plan determines the operations of the civil protection, rescue and relief forces and includes some basic tasks and responsibilities of other entities and bodies, but does not sufficiently replace the necessary crisis management plan, which should define the operation on the political, strategic level.

After an epidemic was declared, without a comprehensive crisis management plan for an infectious disease, version 1.0 of the National Protection and Rescue Plan (No. 84200-1/2016/5, 11 February 2016) was activated (GOV.SI, 12 March 2020).

The above circumstances meant the National Protection and Rescue Plan (version 1.0) was the only option available to the government. The plan specified a risk assessment for the event of an epidemic, the operation of protection, rescue and relief forces, the notification, warning, alerting and management of the epidemic based on the roles of the government and the ministries. However, the plan's descriptions of their tasks and roles are too general and insufficient for a complex crisis response, as was shown later (GOV.SI, 4 May 2020) since it did not sufficiently include the strategic, political level of response. In this version of the plan, the overall response to the epidemic should be coordinated by the Ministry of Health while the operational forces should be led by the Civil Protection Commander. This arrangement would be sufficient so long as the proportions of the Covid-19 epidemic stayed within the response capacities of these two stakeholders.

The result was that only a few specific parts of the National Protection and Rescue Plan (version 1.0) have been relied on. Other activities not defined in detail in the plan have been decided and conducted separately from the plan in an improvised manner (e.g. ad hoc coordination structures, the distribution of personal protective equipment and tests, mass testing and vaccination plans etc.).

The tendency and normative commitment to design a comprehensive crisis management plan did not persist once the first lockdown ended. The government decided to improve version 1.0 of the National Protection and 
Rescue Plan, whereby some solutions from the mentioned crisis management field were applied. The National Protection and Rescue Plan in the event of a communicable disease epidemic or pandemic in humans, version 2.0 (No. 84200-2/2020/3, 23 July 2020, 'version 2.0 of the National Protection and Rescue Plan') is an upgraded version of the old plan, with detailed action plans of individual stakeholders as an integral part. It also includes pre-prepared draft decrees and other necessary documents to facilitate the work of government during an epidemic.

Although a comparison of the two versions of the plan reveals an improvement, some elements of a crisis management plan remain missing: 1) a detailed response plan on the strategic level; 2) a detailed response plan based on the different scenarios already experienced during the Covid-19 epidemic; 3) plans for specific necessary activities such as mass testing and vaccination; 4) expected measures to limit the impacts of the crisis with a timeframe; and 5) a post-crisis analysis plan.

The absence of a comprehensive crisis management plan and the way in which version 2.0 of the National Protection and Rescue Plan was adopted between the two lockdowns reveal improvisation in the planning and application of plans during the epidemic.

While version 2.0. of the Plan includes many elements of a crisis management plan and in a way includes the response on a strategic level and the institutions know how to act during an epidemic, a new crisis will one day emerge. This will again call for improvisation while applying measures from different national protection, rescue and relief plans and implementing ad hoc solutions. Slovenia had similar experiences with the 2014 sleet and 2015-2016 migrant crises and, despite the normative commitment, comprehensive crisis management plans are still not in place. The reasons for this may be found in the lack of decision-makers' awareness of the possible risks and catastrophic consequences of crisis management 'done wrong'. The second reason lies in the failures by the previous and current government to consistently implement the normative commitments. While the former missed the normatively prescribed deadlines for creating crisis management plans, the latter ignored the pre-existing crisis management structure when introducing version 2.0 of the National Protection and Rescue Plan. Moreover, it overlooked the structure while amending the Decree on the National Security Council, resulting in exclusion from the Decree of the National Security Council Secretariat Operational Group, the body responsible for coordinating the preparation of national crisis management plans. 


\section{Crisis decision-making and coordination}

As specified on the normative level, in a complex crisis the Government of the Republic of Slovenia decides on which measures to apply in response to such an event based on recommendations and proposals prepared by the National Security Council and its Secretariat (Government of the Republic of Slovenia Act, Article 20; Final Report P7, 2016: 37). The government should decide to activate crisis management bodies and at the same time assign the coordinating function to the National Security Council Secretariat and to its Head. The function of the Head of the National Security Council Secretariat, as well as the function of the State Secretary in the Prime Minister's Office responsible for national security, requires crisis management knowledge, experience and skills (Final Report P7, 2016: 10-11). To ensure knowledge from the field most affected by a complex crisis, an expert from the ministry or subsystem of the national security system where the crisis first emerged should be appointed as the deputy crisis coordinator (Final Report P7, 2016: 36-37).

During the Covid-19 epidemic, decision-making concerning the crisis has become the sole responsibility of the government. The government decides

640 on all issues related to the epidemic, issues decrees on measures to reduce the risk of infection and the spread of the Covid-19 virus, and confirms the intervention measures to ease the epidemic's consequences before they are discussed in the National Assembly.

The government has established several counselling and working groups: 1) the Expert Counselling Group on Containment and Management of the Covid-19 Epidemic to prepare expert opinions and proposals for measures, verify their justification, and propose their application, amendment or abolition, and monitor the epidemiological situation (GOV. SI, 9 November 2020); 2) the Interdepartmental Working Group for the Review and Evaluation of Purchase Offers of Personal Protective Equipment for Preventing the Spread of the Covid-19 Virus, which was terminated in July 2020 (GOV.SI, 8 April 2020, Dnevnik, 8 July 2020); and 3) an advisory group to prepare strategic measures and draft acts for preventing and mitigating the epidemic's impacts (GOV.SI, 3 December 2020). This demonstrates a considerable level of improvisation in the decision-making process.

As specified by the Decree on the National Security Council, this body consults with the government. In the final days of the previous government when the virus had still to reach Slovenia, the National Security Council confirmed the measures to curb the Covid-19 virus' spread, while after the new government's transition to power the National Security Council held another two meetings. At its May session, it adopted the recommendations to prepare a new National Protection and Rescue Plan (to replace version 
1.0) while at its October session before the second lockdown it assessed the government's measures to combat Covid-19 as being effective and called on citizens to follow the recommendations and measures (GOV.SI, 9 March 2020, GOV.SI, 4 May 2020, GOV.SI, 9 October 2020).

Even more improvisation is evident in coordination of the response to the epidemic. The government did not decide to give the coordinating function to the Head of the National Security Council Secretariat, but instead set up an ad hoc Crisis Staff that was abolished just 9 days after being established (GOV.SI, 14 March 2020; Potič, 2020). Coordination of the strategiclevel response to the epidemic was then taken over by the government ${ }^{2}$.

\section{Crisis communication between the authorities and the public}

Based on version 2.0 of the National Protection and Rescue Plan ${ }^{3}$, the initial message containing information about the epidemic should be released to the public by a representative of the Ministry of Health along with one from the National Institute of Public Health (NIJZ) which, together with the relevant ministries, are responsible for coordinated and timely communication on the national level and for providing the communication content. The government may appoint a government spokesperson.

The Communication Plan in version 2.0 of the National Protection and Rescue Plan stresses:

- enhancing public trust in information and the measures adopted;

- coordination of the communicated information between ministries and other bodies;

- the coordination of press conferences by the Government Communication Office (UKOM); and

- simultaneous and coordinated information-sharing through various media.

Pursuant to the Decision on the tasks of the Government of the Republic of Slovenia Communication Office (Official Gazette of the Republic of Slovenia, Nos 77/03 and 16/07), one task of UKOM is to share expertise and support the ministries' endeavours to professionalise their public relations offices. Under Article 12 of the Decree on crisis management and

2 This arrangement was also included in version 2.0 of the new National Protection and Rescue Plan (adopted in summer 2020) according to which the government coordinates, supervises and shapes the response of the ministries, national security sub-systems and other institutions in the event of an epidemic. The government shares this competence with the Ministry of Health, while the Civil Protection Commander is responsible for activating the National Protection and Rescue Plan and the civil protection operations.

3 The communication process set out in the National Plan is only relevant if an epidemic is officially declared. 
governance and on the National Crisis Management Centre, expert support and coordination of the ministries' crisis communication is to be provided by UKOM. Further, the Mass Media Act (Official Gazette of the Republic of Slovenia, Nos 110/06 - 67/19, Article 25) and the Protection Against Natural and Other Disasters Act (Official Gazette of the Republic of Slovenia, Nos 51/06 - 21/18, Article 55) oblige the national TV and radio broadcaster, the Slovenian Press Agency and, if necessary, other media outlets to publish an emergency warning and further information about a serious threat, without delay or cost.

In practice, information about the first Covid-19-positive patient was communicated by the Minister of Health and a representative of the NIJZ on the evening of 4 March (MMC, 4 March 2020).

On 9 March, UKOM coordinated a press conference featuring the Minister of Health, the Prime Minister, and the Director of NIJZ as speakers (GOV.SI, 9 March 2020). The Minister of Health announced that an epidemic would be declared. The Director of NIJZ spoke about the health situation and development of the outbreak. The Prime Minister explained the overall impact of a national lockdown on the economy and reported the lack of medical protective equipment. At the time of the transition from one 642 government to another, both politicians and epidemiologists were communicating with the public.

The new government appointed a government spokesperson, an expert counselling group ${ }^{4}$ and an expert spokesperson, who was not an epidemiologist. Various experts explained the need for the recommendations and measures introduced. 'Political communication' was based on the 'carrot and stick' principle. During both lockdowns, the communication was mostly negative, threatening the citizens with consequences and even greater restrictions or the loss of freedoms. The government spokesperson occasionally spoke in a cynical tone, seeking to place blame for the spread of the virus. ${ }^{5}$

From March 2020 until the date of writing, opinions on the measures adopted to limit the virus' spread have not always been synchronised and expert advice has been often ignored by the government. Sotlar, Grizold and Vuga Beršnak's analysis (2020) already revealed that certain recommendations were unsynchronised. For example, the recommendations on the use of facemasks issued in early March 2020 were unclear, with some

\footnotetext{
4 The Expert Counselling Group on Containment and Management of the Covid-19 Epidemic.

5 During the spring lockdown, blame for the virus' rapid spread was placed on young people and outdoor gatherings. Similar accusations were repeated at the end of summer, when the virus was allegedly brought in from parties on the Croatian coast. During early autumn, weddings, parties and other gather ings etc. were primarily held as responsible for the spread of the virus. As the end of November approached, lunch breaks at the workplace were held responsible for the virus'spread.
} 
experts even discouraging their use. There were also differences in opinion between the NIJZ director as a representative of epidemiological experts and the government (e.g. Dnevnik, 3 April 2020), leading to inconsistent information about the need for facemasks.

Behaviour that has tarnished the level of trust in politicians and raised doubts about the severity of the virus includes breaches of the recommendations and even the imposed measures by politicians. For several months, politicians and experts did not wear facemasks at press conferences or while being interviewed. From 9 October on (RTV SLO, 9 October), after the Prime Minister delivered a speech while wearing a facemask, facemasks became a best practice among experts as well as politicians. This conveyed to the Slovenian public that, finally, following several months of a global pandemic, the rules apply to everyone, with no double standard. Still, the communication on facemask use had already planted the first seeds of distrust among the public.

Another likely driver of doubt was the occasional lack of coordination in communication. Some messages changed from afternoon till evening, while spokespersons created the feeling that even they did not know the measures in detail. One example is the prime minister himself. At a press conference on 18 October 2020 (GOV.SI, 18 October), he did not mention the possibility of an epidemic again being declared. However, later that day he tweeted (Twitter, 18 October) that an epidemic would be declared the next day. Choosing not to share this information at the official press conference, but instead tweeting it out later to approximately $10 \%$ of the population $^{6}$, might be understood as distrust in the population's political maturity and as questioning whether politicians believe the public is simply not interested or unable to understand political decisions.

Yet another case of poor communication is the information provided about home schooling. During the first lockdown, home schooling was seen as inappropriate for children by exposing and deepening the educational inequalities among them. ${ }^{7}$ While the Minister of Education had stated that schools would be the last to close during any autumn lockdown, they were already closed by the end of October, and it was not until 12 November that the Minister publicly revealed the data on which the decision to switch to home schooling was made (Tarča, 12 November). ${ }^{8}$ Such unwillingness to

6 The estimated number of Twitter users in Slovenia (Računalniške novice, 2020).

7 Over the summer, the minister spoke reassuringly that all levels of the education system were prepared for any potential autumn/winter home schooling.

8 The share of infected pre-school and schoolteachers was about four times higher than among the general population because many had refused to wear facemasks while teaching. High school teachers and university professors were wearing masks in class, resulting in a lower average share of infected persons in this population. 
share information on time could be publicly perceived as hiding facts or as a lack of trust in people's ability to understand the reasons for a certain measure.

The public found especially challenging the travel restrictions prohibiting travel between municipalities, the curfew, and the limitation on gatherings. Although this complex crisis is medical in nature (with various psychological and social impacts) and society has been struggling to limit the number of lives lost, the measures imposed were regularly commented on by the Minister of the Interior, who chastised families for going on walks in nature and threatened to further restrict personal freedoms. ${ }^{9}$ Here we might add that the exceptions made for the owners of property in Croatia were perceived negatively as the public attributed this exception to the fact that some politicians own holiday houses there. Public opinion was that the virus had been politicised, with Covid-19 being dubbed the 'poor people's virus'.

All of the mentioned miscommunication examples further deepened the distrust ${ }^{10}$ and created both a feeling of uncertainty among the public and dissatisfaction because the measures were not always communicated on time or clearly, while the communication sometimes revealed a lack of trust 644 in people's ability to do the right thing and follow the rules.

Autumn brought negativism and general hopelessness, which had been less prominent during the spring lockdown. Motivation and encouragement were therefore greatly needed. The government noticed changes in the public morale and psychologists joined the press conferences, offering some approaches to strengthen mental health and limit anxiety and stress (e.g. RTV SLO, 2 November), but they were unable to neutralise the communication tone of certain speakers nor the overall sense of public dissatisfaction.

The prime minister added to the anxiety described above by stating that for tackling the epidemic the key contribution "for most of the population, is lying on the couch and watching television" (RTV SLO, 19 November 2020). His statement reveals a lack of understanding of the average citizen's everyday life and the distress it has caused. Some have been trying to balance on-going work, home schooling and housework, while others have been struggling with the consequences of social distancing such as loneliness and depression. The Covid-19 epidemic and national lockdowns have

9 The outcome of the minister's authoritarian and threatening communication was a strengthening of distrust, distress and revolt among the population. The minister went as far as to hold the media and supposedly unprofessional reports about Covid-19 responsible for the violent protests in the Slovenian capital in November 2020 (and thus the virus'spread) (Odmevi, 5 November 2020; Delo, 6 November 2020).

10 The data reveal very low trust in politicians and a much higher level of trust in health experts and specialists in infectious diseases, epidemiology, immunology, microbiology etc. (Valicon, 2020). 
had myriad effects, but have in no way amounted to 'a relaxing, fun time with people lounging around on sofas and watching their favourite shows'.

In his early speeches, the prime minister positioned communitarian values in the centre of this epidemic struggle and encouraged people to keep their health and the health of others in mind. Yet, in contrast, his 'Twitter communication' appeared to be the unsynchronised action of an individual rather than part of a modern social media approach used by national leaders.

The analysis revealed a significant level of improvisation during the crisis communication process. Despite the communication being appropriately organised, the communication style seemed inappropriate for Slovenia's social and cultural environment. We have witnessed a lack of empathy and an inability to understand the distress among various groups of people caused by this situation.

Perhaps certain measures would have been more easily accepted by people if: 1) the facts had been presented on time; 2) the reasons for a specific measure had been explained clearly along with their expected contribution to reducing the virus' spread and a realistic time frame; and 3) the impact of each measure on public health had been presented. Instead, the restrictions have been communicated in an authoritarian way, supported with very little research to prove the effectiveness of a certain measure, even after 1 year of the pandemic.

\section{Conclusion}

The overview of the laws on crisis management, infectious diseases, crisis communication and civil protection allows the general conclusion that Slovenia was not completely unprepared for a crisis such as the Covid-19 epidemic, giving rise to expectations that the crisis response would also not be too improvised. While certain acts and guidelines provided adequate procedures and determined the actors responsible for a complex crisis like the Covid-19 epidemic, the government has failed to follow the official crisisresponse documents. Two general reasons explain this: 1 ) the previous government did not meet its obligation to create comprehensive plans based on the normative framework; and 2) the new government has ignored the normatively defined crisis management structure and preferred to improvise considerably. The ignorance of the prescribed solutions and the reasons behind it were not subject to any wider public discourse. Unofficial sources, however, have indicated a rejection of solutions stemming from previous governments and the incumbent prime minister's need for scrutiny.

Not everything can be foreseen in plans, meaning that a certain degree of improvisation in response to various contingencies is always present. 
Nevertheless, comprehensive crisis management and response plans for different events are essential for maintaining preparedness and keeping improvisation on the optimal level and, thereby, for ensuring a rapid, efficient and effective crisis response. Given the absence of adequate crisis management plans in Slovenia, some level of improvisation was expected, leading to the use of the national protection and rescue plan and its adaptation between the spring and autumn lockdowns. Despite the improvement, the in-depth planning of operations on the strategic level remains missing.

On the other hand, the decision-making, coordination and crisis communication processes in case of a complex crisis were normatively well defined. The government has in principle followed the established decision-making practice, yet the analysis identified several cases of improvisation, such as rapid, overnight decisions sometimes inconsistent with the recommendations of the appointed expert groups, and the establishment and abolition of ad hoc structures (e.g. Crisis Staff).

The government has also often relied on improvisation in its public and media communication during the epidemic. It has appointed a spokesperson and included various experts at press conferences, yet certain politicians have not followed the general principles of crisis communication and instead applied a 'carrot and stick' approach. The communication has often been negative, threatening ever greater restrictions, and occasionally even cynical when seeking to place blame for the spread of the virus. The performances of individual actors have not always been synchronised and messages have changed, even on the same day. All of this has given Slovenian society, which is uncertainty-avoiding ${ }^{11}$ and willing to follow the adopted measures to reduce the virus' spread, but does not appreciate the harsh authoritarian communication based on orders, accompanied by poor explanations, the feeling that the government and experts do not know the measures in detail, are unwilling to share information, or have underestimated the public's understanding of the matter. With this information readily available and with an educated and media-savvy public, such a communication style is unacceptable, even when faced with a complex crisis. Authoritarian communication and threats of even greater restrictions have led to a general feeling of humiliation, helplessness, lack of control, mistrust and resentment, with these feelings having deepened when some politicians did not comply with their own recommendations and measures.

The answer to the research question: "To what extent were the actions of the crisis management authorities planned and prepared for, and to what extent were those actions a matter of improvisation?", we can say that quite considerable improvisation was present in all key elements of the Covid-19

11 According to Hofstede's (2001) model for national culture as applied to Slovenia. 
response in Slovenia. The absence of the comprehensive crisis management plan ${ }^{12}$ led to improvisation and the use of the National Protection and Rescue Plan as the only option. On the other hand, while coordination in the case of a crisis was normatively prescribed, the government decided not to activate it and to instead establish the Crisis Management Staff, which it abolished a few days later. The decision-making process and communication with the public were less improvised because the government has kept to the normatively prescribed role and procedures. Nevertheless, the analysis has shown a high level of improvisation also in these two dimensions of the Covid-19 response since the government has sought help by setting up several groups to help with decision-making but failed to include experts from various fields. Hence, the decisions were first based on the perception of the crisis being mostly a health crisis, while ignoring the other impacts. Second, the government has not always followed the recommendations of its own expert groups. Finally, the government has followed the communication procedures but ignored the public's information needs and used ways of communicating with public inappropriate for Slovenian society. The analysis has stressed that, while the response to the epidemic was planned to a certain degree and response structures were available, the government has resorted to improvisation more than necessary.

General experience shows that crises have offered opportunities that led to new and better crisis response solutions. Although the Covid-19 crisis is still not over, the analysis reveals several cases of questionable operation by the Government of the Republic of Slovenia thus far. However, the crisis continues to provide a learning opportunity for more coordinated operation and better communication with the public.

\section{BIBLIOGRAPHY}

Alexander, D. (2020): Covid-19: Plans, Procedures and Improvisation. Published by Saqar 'M Al Zaabi, 15 April. Accessible at https://blogs.ucl.ac.uk/irdr/2020/04/15/ covid-19-plans-procedures-and-improvisation/, 1. 9. 2020.

Deterala, S. and E. B. Villar (2019): Knowing from a Distance: An Improv(is) ed Dialogue About Constellations of Meaning. Prism: Casting New Light on Learning. Theory and Practice 2 (2): 4-19.

Drabek, T. E. (2001): Coordinating Disaster Response: A Strategic Perspective, paper presented at the Western Social Science Association Meeting, 18 April, Reno, NV.

Frykmer, T., C. Uhr, H. Tehler (2018): On Collective Improvisation in Crisis Management - A Scoping Study Analysis. In Safety Science 110: 100-109. Accessible at https://doi.org/10.1016/./j.ssci.2018.02.028, 15. 8. 2020.

12 The Plan should have been prepared several years ago by the relevant ministries, along with other complex crises response plans, but the administration responsible failed to perform this task. 
Kendra, J. and T. Wachtendorf (2006): Improvisation, Creativity, and the Art of Emergency Management. Presented at the NATO Advanced Research Workshop, 8-9 September, Washington D.C.

Kendra, J. and T. Wachtendorf (2016): American Dunkirk: The Waterborne Evacuation of Manhattan on 9/11. Philadelphia: Temple University Press.

Kreps, G. (1991): Organizing for Emergency Management. In Drabek, T. E. and Hoetmer, G. J. (eds.), Emergency Management: Principles and Practice for Local Government, 30-54. Washington D.C.: International City Management Association.

Mendonca, D., G. Webb, C. Butts and J. Brooks (2014): Cognitive Correlates of Improvised Behaviour in Disaster Response: The Cases of the Murrah Building and the World Trade Center. In Journal of Contingencies and Crisis Management 2 (4): 185-195. Accessible at https://doi.org/10.1111/1468-5973.12057, 16. 8. 2020.

Pina e Cunha, M., E. Gomes, K. Mellahi, A. S. Miner and A. Rego (2019): Strategic Agility through Improvisational Capabilities: Implications for a Paradoxsensitive HRM. Human Resource Management Review 30 (1). Accessible at https://doi.org/10.1016/j.hrmr.2019.100695, 18. 8. 2020.

Prezelj, Iztok (2007): Uvod v ocenjevanje ogrožanja nacionalne varnosti. In Prezelj, I. (ed.), Model celovitega ocenjevanja ogrožanja nacionalne varnosti Republike Slovenije, 14-15. Ljubljana: Ministrstvo za obrambo.

Sotlar, A., Anton Grizold and Janja Vuga Beršnak (2020): Institucionalizacija zagotavljanja nacionalne varnosti Republike Slovenije: konceptualizacija, razvojni mejniki, politika in sistem. Ljubljana: Fakulteta za družbene vede, Založba FDV.

Tierney, K. (2012): Decisions in Disaster: Smart People, Smart Institutions? Colorado: Natural Hazards Center, University of Colorado GUIRR.

Vuga Beršnak, J. and A. Ferlin (2018): Priprave in odziv na kompleksno krizo. Ljubljana: Ministrstvo za obrambo RS.

Wachtendorf, T. and J. M. Kendra (2005): A Typology of Organizational Improvisation During Disaster. Presented at the annual meeting of the American Sociological Association, Philadelphia, PA.

Wachtendorf, T. and J. M. Kendra (2006): Improvising Disaster in the City of Jazz: Organizational Response to Hurricane Katrina. Social Science Research Council.

Webb, G. R. and F-R Chevreau (2006): Planning to Improvise the Importance of Creativity and Flexibility in Crisis Response. In International Journal of Emergency Management 3 (1): 66-72.

\section{SOURCES}

D-1000 Communication plan. National Protection and Rescue Plan in the event of a communicable disease epidemic or pandemic in humans, Version 2.0. Slovenian version only accessible at http://www.sos112.si/slo/tdocs/d_1000. pdf, 12. 11. 2020.

Decision on the tasks of the Government of the Republic of Slovenia Communication Office, Official Gazette of the Republic of Slovenia, Nos 77/03 and 16/07. Slovenian version only accessible at http://www.pisrs.si/Pis.web/ pregledPredpisa? id=SKLE4182, 12. 11. 2020. 
Decree on crisis management and governance and on the National Crisis Management Centre. Official Gazette of the Republic of Slovenia, No. 28/18. Slovenian version only accessible at https://www.uradni-list.si/glasilo-uradnilist-rs/vsebina/2018-01-1238?sop=2018-01-1238\#, 12. 11. 2020.

Decree on the National Security Council. Official Gazette of the Republic of Slovenia, No. 26/20. Slovenian version only accessible at https://www.uradnilist.si/glasilo-uradni-list-rs/vsebina/2020-01-0576/odlok-o-svetu-za-nacionalnovarnost, 10. 11. 2020.

Delo, 6 November 2020. Obsodbe se vrstijo, a vprašanje je, kdo je proteste sploh organiziral: Četrtkove izgrede na ljubljanskih ulicah so politiki obsodili. Accessible at https://www.delo.si/novice/slovenija/obsodbe-se-vrstijo-a-glavno -vprasanje-ostaja-kdo-je-proteste-organiziral/, 12. 11. 2020.

Dnevnik, 8 July 2020. Vlada naložila pripravo trimesečnih zalog medicinskotehničnih sredstev. Accessible at: https://www.dnevnik.si/1042933665, 7. 12. 2020.

Final Report P7 (2016): Crisis Management System in the Republic of Slovenia. in Vuga Beršnak, J. (ed)., Ljubljana: Ministry of Defence of the Republic of Slovenia. Slovenian version only accessible at https://www.gov.si/assets/ministrstva/ MO/Publikacije/Zakljucno-porocilo-projekta-P7-Sistem-kriznega-upravljanja-invodenja -v-Republiki-Sloveniji.pdf, 12. 11. 2020.

GOV.SI, 9 March 2020. Svet za nacionalno varnost sprejel ukrepe za zajezitev širjenja koronavirusa. Accessible at https://www.gov.si/novice/2020-03-09-svet-za-nacionalno-varnost-sprejel-ukrepe-za-zajezitev-sirjenja-koronavirusa/, 12. 11. 2020.

GOV.SI, 12 March 2020. Slovenija razglasila epidemijo novega koronavirusa. Accessible at https://www.gov.si/novice/2020-03-12-slovenija-razglasila-epidemijo-novega-koronavirusa/, 27. 11. 2020.

GOV.SI, 14 March 2020. Krizni štab Republike Slovenije o konkretnih ukrepih za zajezitev epidemije. Accessible at https://www.gov.si/novice/2020-03-14-kriznistab-republike-slovenije-o-konkretnih-ukrepih-za-zajezitev-epidemije/, 1. 5. 2021.

GOV.SI, 8 April 2020. Nabava zaščitne opreme mora biti transparentna. Accessible at https://www.gov.si/novice/2020-04-08-nabava-zascitne-opreme-mora-bititransparentna/, 8. 12. 2020.

GOV.SI, 4 May 2020. Seja Sveta za nacionalno varnost. Accessible at https://www. gov.si/novice/2020-05-04-seja-sveta-za-nacionalno-varnost/, 6. 12. 2020.

GOV.SI, 9 October 2020. Predsednik vlade Janez Janša: Svet za nacionalno varnost ocenjuje, da smo na prelomni točki, kjer lahko zaenkrat še z mehkimi ukrepi zajezimo širjenje koronavirusa. Accessible at https://www.gov.si/novice/202010-09-predsednik-vlade-janez-jansa-svet-za-nacionalno-varnost-ocenjuje-dasmo-na-prelomni-tocki-kjer-lahko-zaenkrat-se-z-mehkimi-ukrepi-zajezimo-sirjenje-koronavirusa/, 29. 11. 2020.

GOV.SI, 18 October 2020. Predsednik vlade Janez Janša: Pred nami je zahtevno hladno obdobje pandemije, ki od nas terja učinkovito ukrepanje, predvsem pa visoko stopnjo odgovornosti in solidarnosti. Accessible at https://www.gov.si/ novice/2020-10-18-predsednik-vlade-janez-jansa-pred-nami-je-zahtevno-hladno- 
obdobje-pandemije-ki-od-nas-terja-ucinkovito-ukrepanje-predvsem-pa-visokostopnjo-odgovornosti-in-solidarnosti/, 13. 11. 2020.

GOV.SI, 3 December 2020. Odpravljanje posledic epidemije. Assessible at https:// www.gov.si/teme/koronavirus-sars-cov-2/odpravljanje-posledic-epidemije/, 7. 12. 2020.

Government of the Republic of Slovenia Act. Official Gazette of the Republic of Slovenia, Nos 24/05 - 55/17. Slovenian version only accessible at http://pisrs.si/ Pis.web/pregledPredpisa?id=ZAKO242, 20. 10. 2020.

Infectious Diseases Act. Official Gazette of the Republic of Slovenia, Nos 33/06 175/20. Slovenian version only accessible at http://www.pisrs.si/Pis.web/

pregledPredpisa?id=ZAKO433, 3. 12. 2020.

Mass Media Act. Official Gazette of the Republic of Slovenia, Nos 110/06 67/19. Slovenian version only accessible at http://pisrs.si/Pis.web/pregled Predpisa?id=ZAKO1608, 12. 11. 2020.

MMC, 4 March 2020. Prvi potrjeni primer okužbe pri nas: okuženi prišel iz Maroka prek Italije: Sproženi so bili ustrezni protokoli. Accessible at https://www.rtvslo. si/zdravje/novi-koronavirus/prvi-potrjeni-primer-okuzbe-pri-nas-okuzeniprisel-iz-maroka-prek-italije/516153, 12. 11. 2020.

National Protection and Rescue Plan in the event of a communicable disease epidemic or pandemic in humans, Version 1.0. No. 84200-1/2016-5, 11 February 2016. Ljubljana: Government of the Republic of Slovenia.

National Protection and Rescue Plan in the event of a communicable disease epidemic or pandemic in humans, Version 2.0. No. 84200-2/2020/3, 23 July 2020. Slovenian version only accessible at http://www.sos112.si/slo/tdocs/epidemija_pandemija.pdf, 12.11. 2020.

Odmevi, 5 November 2020. Accessible at https://4d.rtvslo.si/arhiv/odmevi/ 174730332, 13. 11. 2020.

Potič, Zoran. Dnevnik, 25 March 2020. Krizni štab ukinjen, ker se je vlada utekla. Accessible at https://www.dnevnik.si/1042925551, 7. 12. 2020.

Protection Against Natural and Other Disasters Act. Official Gazette of the Republic of Slovenia. Nos 51/06 - 21/18. Slovenian version only accessible at: http://pisrs. si/Pis.web/pregledPredpisa?id=ZAKO364, 5. 1. 2021.

Računalniške novice, 14 January 2020. Profil na vsaj enem družbenem omrežju ima 1,25 milijona prebivalcev Slovenije. Accessible at https://www.racunalniske-novice.com/novice/splet/socialna-omrezja/facebook/profil-na-vsaj-enemdruzbenem-omrezju-ima-125-milijona-prebivalcev-slovenije.html?RSSb372f343 431cb16050806eded31fb830, 13. 11. 2020.

Resolution on the National Security Strategy of the Republic of Slovenia. Official Gazette of the Republic of Slovenia, No. 59/19. Slovenian version only accessible at: uradni-list.si/glasilo-uradni-list-rs/vsebina/2019-01-2618?sop=2019-01-2618, 20. 10. 2020.

RTV SLO, 2 November 2020. Najnovejše o koronavirusu, prenos novinarske konference. Accessible at https://www.rtvslo.si/4d/arhiv/174729483?s=dostopno, 13. 11. 2020. 
RTV SLO, 19 November 2020. "Če bi julija zapirali državo, bi nas verjetno ob tistih podatkih razglasili za nore”. Accessible at https:/www.rtvslo.si/slovenija/ ce-bi-julija-zapirali-drzavo-bi-nas-verjetno-ob-tistih-podatkih-razglasili-za-nore /542877, 8. 1. 2021.

Tarča, 12 November 2020. Šolanje na daljavo. Accessible at https://4d.rtvslo.si/ arhiv/tarca/174731947, 13. 11. 2020.

Twitter, 18 October 2020. Accessible at https://twitter.com/JJansaSDS/status/ 1317892910633930758, 13. 11. 2020.

Valicon, 10 October 2020. Accessible at https://www.valicon.net/sl/2020/10/zaupanje-v-kljucne-predstavnike-vlade-in-stroke/, 13. 11. 2020. 